\title{
Rove beetles (Coleoptera: Staphylinidae) on agrolandscape herbaceous vegetation in the Leningrad Region
}

\section{Стафилиниды (Coleoptera: Staphylinidae) на травянистой растительности агроландшафтов Аенинградской области}

\author{
O.G. Guseva ${ }^{1}$, A.M. Shpanev ${ }^{1,2}$ \\ О.Г. Гусева ${ }^{1}$, А.М. Шпанев ${ }^{1,2}$
}

\footnotetext{
${ }^{1}$ All-Russian Institute of Plant Protection, Podbelskogo 3, St. Petersburg, Russia. E-mail: olgaguseva-2011@yandex.ru

${ }^{1}$ Всероссийский НИИ защиты растений, шоссе Подбельского, 3, Санкт-Петербург, Россия.

2 Agrophysical Research Institute, Grazhdanskiy Pr. 14, St. Petersburg, Russia.

2` Агрофизический НИИ, Гражданский проспект 14, Санкт-Петербург, Россия.
}

KEY WORDS: biodiversity, rove beetles, sweep netting, herbaceous vegetation, agrolandscape.

КЛЮЧЕВЫЕ СЛОВА: биоразнообразие, стафилиниды, кошение энтомологическим сачком, травянистая растительность, агроландшафт.

ABSTRACT. During the period from 2005 to 2019, 38 rove beetles species were collected by sweeping herbaceous vegetation in agricultural fields and at field margins of the Leningrad Region, Northwestern Russia. The highest species diversity is recorded on the grain crops and at field margins. Eleven of the collected species $(29 \%$ of the total number of species collected by sweep sampling) were never collected by pitfall traps. Among them Stenus similis (Hbst.), frequently collected in herbaceous layer, mainly on perennial grasses and winter grain crops.

РЕЗЮМЕ. За период с 2005 по 2019 г. в Ленинградской области на травянистой растительности методом кошения энтомологическим сачком было собрано 38 видов стафилинид. Наибольшее видовое разнообразие отмечено в агроценозах зерновых культур и на обочинах полей. 11 видов стафилинид (29\% от общего числа видов стафилинид, собранных методом кошения) не были отмечены при учётах, проведённых с помощью почвенных ловушек. Среди этих видов Stenus similis (Hbst.), часто встречающийся в растительном ярусе, особенно на полях многолетних трав и озимых зерновых культур.

\section{Introduction}

Many species of rove beetles (Coleoptera, Staphylinidae) occur in boreal agrolandscapes, mainly on soil surface. In total, 157 species of rove beetles have been found on soil surface in the in the agrolandscapes in
Northwestern Russia [Guseva, 2014a]. Their role as predators of agricultural pests that live on plants depends on their ability to climb different plants. Nevertheless, this ability of many species has not yet been clarified in the existing literature. Sweeping on vegetation is rarely used to collect rove beetles [Niedobova, Fric, 2014]. This study determines the species composition of rove beetles on the plants by sweeping vegetation on different agricultural fields and at their margins in the Leningrad Region.

\section{Data and methods}

Data were collected during the 2005-2019 period in the framework of a joint project with the Agrophysical Research Institute (ARI, St. Petersburg). Rove beetles were collected with a standard insect net $(300 \mathrm{~mm}$ diameter) in the different biotopes. The research was carried out on grain crops (spring and winter wheat, rye and spring barley), perennial grasses (clover, timothy grass and rye grass), potato, beet, vetch-oat mixture, rape, lupine and at field margins (about 5-10 $\mathrm{m}$ around the cultivated land, the biotope combine herbaceous vegetation and shrubs) mainly at Menkovo Research Station (MRS) of ARI (Menkovo Village, Gatchina District, Leningrad Region). Samples were taken with weekly or bi-weekly intervals from May to August. Whenever possible, sampling was done on warm, dry days. At each sampling site, 50-100 sweeps were made with a sweep net. During the whole sampling period we collected with insect net a total of 347 rove beetles specimens with 40300 sweeps.

How to cite this article: Guseva O.G., Shpanev A.M. 2019. Rove beetles (Coleoptera: Staphylinidae) on agrolandscape herbaceous vegetation in the Leningrad Region // Russian Entomol. J. Vol.28. No.4. P.373-376. doi: 10.15298/rusentj.28.4.05 
Most specimens we identified by us. Some specimens were identified by V.I. Gusarov (Natural History Museum, University of Oslo, Norway) or A.V. Kovalev (All-Russian Institute of Plant Protection, St. Petersburg, Russian Federation). The first also checked and confirmed some of our identifications.

The species richness was estimated by the popular Margalef index $\mathrm{DMg}=(\mathrm{S}-1) / \mathrm{ln} \mathrm{N}$, where $\mathrm{S}$ is the number of species recorded and $\mathrm{N}$ is the total number of individuals of all the species [Pesenko, 1982)].

To compare results obtained by sweeping on vegetation and pitfall trapping, this study uses the data collected during our previous investigations in the agrolandscapes of the Leningrad Region [Guseva, 2014a, b; 2017; 2019; Guseva, Koval, 2015, 2017].

\section{Results and discussion}

In total, 38 species of rove beetles from 8 subfamilies and 23 genera, were collected on herbaceous vegetation using sweep net sampling. The species richness is distributed in various fields as follows: grain crops 26 species, grasses 15 , potato and beet five species (Table).

Among the collected rove beetles, ten species belong to the subfamily Tachyporinae (Tachyporus, Tachinus, Bolitobius, Mycetoporus), nine species belong to Aleocharinae (Oxypoda, Nehemitropia, Amischa, Aloconota, Atheta, Mocyta, Aleochara), five to Steninae (Stenus), five to Omalinae (Eusphalerum, Omalium, Anthophagus), four to Staphylininae (Gyrohypnus, Gabrius, Philonthus) and three to Oxytelinae (Carpelimus, Anotylus) (Table).

It is known, that those representatives of Tachyporinae and Aleocharinae subfamilies that do not have a narrow specialization, are able to climb plant stems, but spend significant amount of time in cavities of the ground [Tikhomirova, 1973].

Among rove beetles from Tachyporinae subfamily, Tachyporus chrysomelinus and T. hypnorum are most abundant on the herbaceous vegetation (Table).

Among rove beetles from Aleocharinae subfamily, $A$. analis and $M$. fungi was most frequently collected on the plants by sweep net sampling. $M$. fungi is especially abundant on the grain crops and perennial grasses (Table).

The Steninae subfamily (Stenus spp.) plays a distinct role among the rove beetles that are able to climb plants. The species of this genus which are encountered on the ground surface and on the plants in wet biotopes, share distinctive features that enable them to move freely across the plants and to resist dehydration [Tikhomirova, 1973]. S. similis in herbaceous layer in the agrolandscapes of the Leningrad Region were especially abundant (Table).

Representatives from Omaliinae subfamily climb plants in order to search for food. It is known that species of the genus Eusphalerum (Omaliinae) feed on pollen [Freude et al., 2012]. E. minutum occurs on flowers of Caltha and Ranunculus [Freude et al., 2012].
The other representative of this genus, E. luteum, was highly abundant in the agrolandscape of MRS at the field margin covered mostly with Filipendula vulgaris (Moench, 1794) and Epilobium angustifolium (Linnaeus, 1753), during their flowering period.

However, most rove beetles are predators. Stenus preys on larvae of Cicadellidae, Diptera and others small arthropods [Freude et al., 2012]. S. similis has been recorded as a predator of aphids Sitobion avenae Fabricius, 1775 [Sunderland et al., 1987]. A. gregaria preys on aphids Rhopalosiphum padi (Linnaeus, 1758) [Guseva, 2011]. Tachyporus spp. are significant predators of aphids and others arthropods. T. hypnorum preys on aphids $R$. padi, Sitobion avenae [Sopp, Wratten, 1986; Kyneb, Toft, 2004] and Acyrthosiphon pisum Harris, 1776 [Balog et al., 2013]. According to field observations in different parts of Turkey, adult beetles of T. nitidulus and T. hypnorum prey upon cereal aphids and eggs of cabbage root flies (Delia sp.) [Özgen, Anlas, 2011]. Tachyporus obtusus feeds on aphids $S$. avenae [Dennis et al., 1991]. Tachyporus chrysomelinus preys on aphids $S$. avenae [Sopp, Wratten, 1986] and $R$. padi [Guseva, 2011]. The level of consumption of aphid $R$. padi by adult $T$. chrysomelinus is $4.2 \pm 3.40$ individuals per day under laboratory conditions [Guseva, 2011]. The study carried out in winter grain fields in the Leningrad Region demonstrated that Tachyporus spp. are present in the crops from the third decade of May, while $S$. similis are present from the second decade of May, before the appearance of aphids on the fields. Abundance of the rove beetles (calculated as the number of specimens per 100 sweeps) on plants of winter grain fields is higher than on the other fields, the highest species diversity is recorded on the grain crops (Table). Probably, grain aphids along with other phytophagous insects attract various species of predatory rove beetles, who climb plants in order to feed. Therefore, they might play an important role as useful predators at the beginning of the appearance of aphids on the winter grain fields.

Among those rove beetles that occurred on the herbaceous vegetation, many species were also known to be abundant on the soil surface. For instance, our previous investigations carried out by pitfall trapping method have shown $T$. chrysomelinus, T. hypnorum, A. analis, $M$. fung $i$ and $A$. gregaria to be among the most numerous species in agrolandscapes of the Leningrad Region [Guseva, 2014b, 2017, 2019; Guseva, Koval, 2015, 2017].

Eleven species: E. luteum, E. minutum, C. ?elongatulus, A. omalinus, O. rufus, S. similis, P. pseudovarians, $T$. ?formosus, T. obtusus, A. debilis and $N$. lividipennis were captured by sweeping herbaceous vegetation, but they have never been found in pitfall traps during the whole period of our research (Table). They constitute a $29 \%$ share of the overall number of species collected on the plants by sweeping. The species that are able to climb plants and to move freely along vertical surfaces presumably do not get caught in pitfall traps or they are able to leave them. This implies that 
Table. Rove beetles collected on herbaceous vegetation in different kinds of agricultural fields and field margins. Таблица. Стафилины, собранные на травянистой растительности различных полей и их обочин.

\begin{tabular}{|c|c|c|c|c|c|c|c|}
\hline \multirow[b]{2}{*}{ Species } & \multirow[b]{2}{*}{ SF } & \multicolumn{6}{|c|}{ Biotope } \\
\hline & & $\begin{array}{l}\text { spring } \\
\text { grain } \\
\text { crops }\end{array}$ & $\begin{array}{l}\text { winter } \\
\text { grain } \\
\text { crops }\end{array}$ & $\begin{array}{c}\text { potato } \\
\text { and beet } \\
\text { fields }\end{array}$ & $\begin{array}{l}\text { annual } \\
\text { grasses }\end{array}$ & $\begin{array}{c}\text { perennial } \\
\text { grasses }\end{array}$ & $\begin{array}{c}\text { field } \\
\text { margins }\end{array}$ \\
\hline Eusphalerum luteum (Marsham, 1802)* & $\mathrm{Om}$ & & & & & & 65 \\
\hline Eusphalerum minutum (Fabricius, 1792)* & Om & 1 & & & & & 52 \\
\hline Omalium caesum Gravenhorst, 1806 & $\mathrm{Om}$ & & 1 & & & & \\
\hline Anthophagus caraboides (Linnaeus, 1758) & Om & & & & & & 1 \\
\hline Anthophagus omalinus Zetterstedt, $1828^{*}$ & $\mathrm{Om}$ & 1 & & & & & \\
\hline Carpelimus ?elongatulus (Erichson, 1839)* & $\mathrm{Ox}$ & & 1 & & & & \\
\hline Anotylus nitidulus (Gravenhorst, 1802) & $\mathrm{Ox}$ & & & 1 & & & \\
\hline Anotylus rugosus (Fabricius, 1775) & $\mathrm{Ox}$ & & & & & & 3 \\
\hline Oxyporus rufus (Linnaeus, 1758)* & Op & & & & 1 & & 1 \\
\hline Stenus cicindeloides (Schaller, 1783) & $\mathrm{Sn}$ & 1 & & & & & \\
\hline Stenus flavipes Stephens, 1833 & $\mathrm{Sn}$ & & & & & & 2 \\
\hline Stenus fulvicornis Stephens, 1833 & $\mathrm{Sn}$ & & 1 & & & 1 & \\
\hline Stenus nanus Stephens, 1833 & $\mathrm{Sn}$ & & & & & 2 & \\
\hline Stenus similis (Hebst, 1784)* & $\mathrm{Sn}$ & 1 & 9 & & & 11 & 9 \\
\hline Rugilus erichsonii (Fauvel, 1876) & $\mathrm{Pd}$ & 1 & & & & & \\
\hline Gyrohypnus angustatus Stephens, 1833 & St & & 1 & & & & \\
\hline Gabrius breviventer Sperk, 1835 & St & 1 & 1 & & & & 2 \\
\hline Philonthus concinmus Gravenhorst, 1802 & St & 1 & & & & & 1 \\
\hline Philonthus pseudovarians A. Strand, 1941* & St & 1 & & & & & \\
\hline Mycetoporus bimaculatus Lacordaire, 1835 & $\mathrm{Tp}$ & 1 & & & 1 & 1 & \\
\hline Bolitobius formosus (Gravenhorst, 1806) & $\mathrm{Tp}$ & & & & & & 1 \\
\hline Tachinus marginellus (Fabricius, 1781) & $\mathrm{Tp}$ & & & & & 1 & \\
\hline Tachinus rufipes (Linnaeus, 1758) & $\mathrm{Tp}$ & & 2 & & & 1 & \\
\hline Tachyporus chrysomelinus (Linnaeus, 1758) & $\mathrm{Tp}$ & 2 & 10 & 1 & 4 & 13 & 8 \\
\hline Tachyporus ?formosus Matthews, $1838^{*}$ & $\mathrm{Tp}$ & 1 & & & & & \\
\hline Tachyporus hypnorum (Fabricius, 1775) & $\mathrm{Tp}$ & 3 & 7 & & 2 & 3 & 2 \\
\hline Tachyporus nitidulus (Fabricius, 1781) & $\mathrm{Tp}$ & 1 & 1 & & & & 1 \\
\hline Tachyporus obtusus (Linnaeus, 1767)* & $\mathrm{Tp}$ & & 1 & & & & 1 \\
\hline Tachyporus pusillus Gravenhorst, 1806 & $\mathrm{Tp}$ & & 1 & & 1 & & 1 \\
\hline Oxypoda brevicornis (Stephens, 1832) & Al & & & & 1 & & \\
\hline Nehemitropia lividipennis (Mannerheim, 1831)* & Al & & & 1 & & & \\
\hline Amischa analis (Gravenhorst, 1802) & $\mathrm{Al}$ & & 10 & & & 28 & 4 \\
\hline Aloconota gregaria (Erichson, 1839) & Al & 1 & 1 & & & 1 & \\
\hline Atheta debilis (Erichson, 1837)* & Al & & & & & & 1 \\
\hline Atheta laticollis (Stephens, 1832) & Al & & 2 & & & & \\
\hline Mocyta fungi (Gravenhorst, 1806) & Al & 9 & 9 & 1 & 4 & 19 & 5 \\
\hline Aleochara bilineata (Gyllenhaal, 1810) & Al & & 1 & 1 & 1 & & \\
\hline Aleochara bipustulata (Linnaeus, 1761) & $\mathrm{Al}$ & 1 & & & & & \\
\hline No of species & & 16 & 17 & 5 & 8 & 11 & 18 \\
\hline No of specimens & & 27 & 59 & 5 & 15 & 81 & 160 \\
\hline Dmg & & 4.54 & 3.92 & 2.48 & 2.58 & 2.28 & 3.35 \\
\hline No of sweeps & & 8000 & 5100 & 4500 & 8300 & 6900 & 7500 \\
\hline Total catchability (specimens per 100 sweeps) & & 0.34 & 1.16 & 0.11 & 0.18 & 1.17 & 2.13 \\
\hline
\end{tabular}

SF — subfamiliy: Om - Omaliinae, Ox — Oxytelinae, Op — Oxyporinae, Sn — Steninae, Pd — Paederinae, St — Staphylininae, $\mathrm{Tp}$ - Tachyporinae, Al - Aleocharinae; * - species was not collected by pitfall trapping.

$\mathrm{SF}$ - подсемейства: Om - Omaliinae, Ox — Oxytelinae, Op — Oxyporinae, Sn — Steninae, Pd — Paederinae, St — Staphylininae, Tp - Tachyporinae, Al - Aleocharinae; * — виды, не собранные в почвенные ловушки. 
sweep netting method has a huge potential to enrich data collection, nowadays focused on the widespread use of pitfall traps.

Acknowledgments. We are sincerely grateful to V.I Gusarov (Natural History Museum, University of Oslo, Norway) and A.V. Kovalev (All-Russian Institute of Plant Protection, St. Petersburg, Russian Federation) for their advice and help with material identification. We would like to thank V.I. Gusarov whose expertise was invaluable in the preparation of this paper. The study was performed within the frames of the Russian State Research Project no. 0665-2018-0008.

\section{References}

Guseva O.G. 2011. [Predatory arthropods as entomophages of cereal aphids (Homoptera, Aphididae) in Northwestern Russia] // Inform. Bull. IOBC/EPRS. No.42. P.63-67 [in Russian].

Guseva O.G. 2014a. [Ground-living predatory beetles and spiders in the agrolandscapes in Northwestern Russia]. Abstract Diss. ...Doct. Biol. Sci. SPb. 42 pp. [In Russian]

Guseva O.G. 2014b. [The rove beetle Aloconota gregaria Er. (Coleoptera, Staphylinidae) as a polyphagous predator in the agricultural landscapes of Northwestern Russia] // Plant Protection News. Vol.1. P.17-20 [in Russian, with English summary].

Guseva O.G. 2017. [Rove beetles (Coleoptera, Staphylinidae) in agricultural landscape of the Leningrad Region] // Plant Protection News. Vol.4. P.39-42 [in Russian, with English summary].

Guseva O.G. 2019. [Investigation of biodiversity and distribution of rove beetles (Coleoptera, Staphylinidae) in the agrolandscape in Northwestern Russia] // Acta Biologica Sibirica. Vol.5. No.1. P.12-18 [in Russian, with English summary].

Guseva O.G., Koval A.G. 2015. Influence of soddy-podzolic soil improvement on the abundance and structure of complexes of epigeic predatory beetles (Coleoptera: Carabidae, Staphylinidae) in Northwestern Russia // Entomological Review. Vol.95. No.8. P.1051-1060.
Guseva O.G., Koval A.G. 2017. [Aleocharines (Staphylinidae, Aleocharinae) in agricultural landscapes with different soil in Northwestern Russia] // Inform. Bull. IOBC/EPRS. No.52. P.99-103 [in Russian].

Balog A., Mehrparvar M., Weisser W.W. 2013. Polyphagous predatory rove beetles (Coleoptera: Staphylinidae) induce winged morphs in the pea aphid Acyrthosiphon pisum (Hemiptera: Aphididae) // Eur. J. Entomol. Vol.110. No.1. P.153-157.

Dennis P., Wratten S.D., Sotherton N.W. 1991. Mycophagy as a factor limiting predation of aphids (Hemiptera: Aphididae) by staphylinid beetles (Coleoptera: Staphylinidae) in cereals // Bull. Entomol. Res. Vol.81. Iss.1. P.25-31.

Freude H., Harde K.W., Lohse G.A. 2012. Die Käfer Mitteleuropas. Bd.4. Krefeld: Goecke \& Evers Verl. $560 \mathrm{~S}$.

Kyneb A., Toft S. 2004. Quality of two aphid species (Rhopalosiphum padi and Sitobion avenae) as food for the generalist predator Tachyporus hypnorum (Col., Staphylinidae) // J. Appl. Entomol. Vol.128. Nos9/10. P.658-663.

Niedobova J., Fric Z.F. 2014. The adequacy of some collecting techniques for obtaining representative arthropod sample in dry grasslands // Acta Univ. Agr. Silvicult. Mendelianae Brunensis. Vol.62. No.1. P.167-174

Özgen I., Anlas S. 2011. New and additional records of the Subfamily Tachyporinae (Coleoptera: Staphylinidae) from Turkey, with observations on agricultural importance of the genus Tachyporus // Türk. entomol. derg. Vol.35. No.2. P.303-312.

Pesenko Yu.A. 1982. [Principles and Methods of Quantitative Analysis in Faunistic Research]. Moscow: Nauka. 288 p. [In Russian]

Sopp P., Wratten S.D. 1986. Rates of consumption of cereal aphids by some polyphagous predators in the laboratory // Entomol. Exp. Appl. Vol.41. No.1. P.69-73.

Sunderland K.D., Crook N.E., Stacey D.L., Fuller B.J. 1987. A study of aphid feeding by polyphagous predators on cereal aphids using ELISA and gut dissection // J. Appl. Ecol. Vol.24. No.3. P.907-933.

Tikhomirova A.L. 1973. [Morphological features and phylogeny of the rove beetles (with catalog of the fauna of the USSR)]. Moscow: Nauka. 192 pp. [In Russian] 